\title{
Do Budget Deficits Cause Inflation? Evidence from Albania
}

\author{
Rexhep Dokja \\ Epoka University \\ Banking and Finance Department
}

\section{Doi:10.5901/ajis.2013.v2n9p764}

\begin{abstract}
The basic purpose of this paper is to analyze this relationship among budget deficit and inflation for Albania. As many cases in history have shown that fiscal imbalances result in inflation problems. Empirical studies indicate strong evidence that budget deficits financed through monetarism and a rising money supply lead to higher inflation. The effect of budget deficits to cause inflation is depended on the means by which it is financed and the impact on aggregate demand. In this paper, the budget deficits and inflation relationships are studied by using data's of Consumer Price Indexes and Budget Deficits of Albania. Data for the time period 1996-2008 are taken for into consideration. The dependent variable is CPI. To find the empirical evidence on these data regression analysis is used.
\end{abstract}

Keywords: Budget deficit, Inflation, Money Supply, Albania

\section{Introduction}

Government participates in the economy as a producer and as a consumer. Firstly, the government provides public goods and services. As a producer, the government focuses on the field of services, for example, national security, regulations, medical care, etc.. To carry out its activity the government collects revenue for its budget, the main part of which is occupied by taxes. But, when expenses exceed revenues the government covers its costs by borrowing. It can also use another way to finance the budget deficit by issuing money, but this approach is associated with consequences act as a tax burden through inflation growth. During the last 30 years budget deficits have been a widespread phenomenon in the world. This has been based on various factors but what are of interest to our analysis are the effects of budget deficits.

Public Debt expresses the full amount of loans taken to finance the annual deficits, which represents the cumulative budget deficits from one year to another. Budget deficit represents the debt of any given year, while public debt represents all debt in a given period, so accumulated debt of all periods.

Main arguments against budget deficits and public debt:

- Deficits and private investment: When the government borrows to finance its deficit it may reduce the funds that businesses can use to invest and expand their capital. Smaller investment means less new real capital, less jobs, less growth in labor productivity and less personal income growth.

- Large deficits can lead to higher interest rates: To finance budget deficits the government may borrow from the same institutions that private firms do: banks, foreign lenders etc.. When the government borrows large amounts it significantly increases the demand for credit funds and it may raise interest rates.

- Deficits and inflation. The government can simply print money to finance higher deficits and pay off debts. This would increase the amount of money in circulation faster than the quantity of goods and services to which the money should be spent. Therefore this would cause inflation.

- Annual interest payments on public debt have been rising. This is true for many countries including Albania. If deficits do not decrease the interest payments will increase, so the budget deficits will increase even more.

\section{Literature Review}

According to Bruno (1995), a high rate of inflation is always accompanied by serious imbalances in public finances. According to him, a detailed analysis shows that, in all cases of inflationary crisis, the country showed large budget deficits before the crisis, still more pronounced during the crisis and clearly below the average during the post-crisis recovery. Empirical observation confirms monetarist proposition that budget deficits contribute to the growth of the money 
supply, and excessive creation of money is responsible for inflation. According to Montiel (1989), supporters of the budget approach, and in particular Milton Friedman, support the idea that inflation is always and everywhere a monetary phenomenon. Theoretical contributions by Sargent and Wallace (1981), Dornbusch (1985 and 1992), Buiter (1984), van Anand Wijnberge et (1987 and 1989), Dornbusch and Fischer (1989), have shown that "the monetary mass permanent expansion essentially arises from budgetary imbalances ". However, empirical work does not always lead to this conclusion. Barro (1978), it is more public spending growth that increases the money supply, rather than the amount of the budget deficit. However, the American experience offers ambivalent results.

Ambiguity of a link between money supply growth and public finance imbalances continues in works dedicated to other developed economies. Thus, Kolluri and Giannaros (1985), and Protopapadakis and Siegel (1986) have tested a model similar to that of Barro for ten industrialized countries. They did not find a significant relationship between budget deficit and money supply growth. On the contrary, for the same sample of countries, Blundell and Chouraqui (1981) find that the acceleration of the growth of money supply corresponds to a certain number of countries with the implementation of expansionary budgetary policies. Contradictory results have been well received by researchers in developing countries. The main reason economists do not bring out significant positive relationship between the amount of public finance imbalances, increasing the money supply and the inflation rate is the way of financing the budget deficit. As a rule, the sale of public debt securities to non-bank private sector or external funding (in the case of floating exchange rate) provides non-monetary financing of the budget deficit. Modigliani (1987) argues that the link between budget deficits and increasing amounts of money is clearly false, at least for economies with a reasonably developed financial system. This relation also depends on economic agents' expectations about future government policy.

Contrary to a good idea spread, according to which bond financing is not inflationary as it's funded through stable savings, Sterdyniak (1983) states that, by diverting savings away from productive investment, the financing of the budget deficit increases interest rates. McCallum (1983) does not find evidence in theory according to which budget deficit does not create inflationary pressures if it is financed through bonds. Sargent and Wallace (1985) have highlighted the inflationary character of the bond financing of budget deficits.

However, it is certainly accepted that monetary financing is inflationary because it causes an increase in the money supply. Thus, in many developing countries and / or countries in transition, inflationary pressure differs from that observed in industrialized countries and / or countries in rapid expansion, due to the important role played by budget deficits, limited development of the domestic financial markets, as well as restrictions on the use of external financing. Due to the narrowness of the domestic financial markets, financing through money creation remains a privileged or last, through which Treasury can get the necessary funds. Chronic hyperinflationary and inflationary pressures are prevalent in many countries that have large budget deficits monetized. Hyperinflationary experience of Central European countries in 1920, that of Greece and Hungary, at the end of World War II have shown that substantial budget deficits are financed mainly through cash. According to Sachs and Larrain (1993) Origin of extreme inflation rates in many Latin American countries lies mainly in continuous and very high budget deficits, so that their funding has also been provided through cash. A recent analysis of twenty-one countries in transition shows that monetary expansion has played a determining role in relation to the rate of inflation (Coorey, Mecagni, and Offerdal, 1998).

\section{Financing of Budget Deficit in Transition Economies Effect on Money Supply}

The government can finance the budget deficit through the advances of the Central Bank or through the sale of public securities. Purchase of public securities by the Central Bank or the provision of a direct loan to the state increases the money supply at the amount of loan obtained by the monetary authority. The government account it is initially increased when it is funded by the Central Bank. But, as these resources are expended, the amount of the debt is partially transferred to the commercial banks. Then, depending on the behavior of commercial banks in the composition of their portfolio, a "medium" monetary mass expansion can occur through the credit multiplier.

Monetary impact of budget deficit financing through commercial banks will depend on whether direct loans or buying Treasury securities will swell public banks portfolio or if they will replace the other assets in the portfolio. If the assets of commercial banks other than loans to governments remain unchanged, a global growing of balance sheet of commercial banks will be. As a result the purchase of public securities or providing a credit to the state increases the money supply in the broad sense by the amount of loans received from the Treasury. However, unlike what happens in the case of a financing by the Central Bank, no increase in the monetary base will occur firstly.

If, on the contrary, banks keep their balance intact or if they do not have excess liquid reserves, other assets, especially lending to the economy tends to be reduced in proportion to their supplementary assets in public securities. Then, in the portfolio of commercial banks, it is a substitution of securities to credit to the economy. If refinancing 
conditions are very strict in public securities, all increase of their public portfolio securities will occur at the expense of credit to the economy. In this case, money supply does not increase and the monetary base does not change. If, on the contrary, there is a use of the Central Bank refinancing of commercial banks to the amount of securities purchased or public lending of the state, an increase of the money supply in broad sense occurs.

Bond financing of budget deficits provides a relatively non-monetary financing of the public finance imbalances. Purchase of securities by non-financial agents, households, businesses and financial institutions outside the banking sector, affects neither the monetary base nor money supply. Which means effectively a simple transfer of property assets of the private sector in public administration and vice versa, when the funds are spent by the latter.

Public securities purchases by non-resident financial agents reduce the amount of deposits and bank reserves, and the bills in favor of increasing the Treasury account at the Central Bank. But when re-sources are spent by the Treasury, is not just an increase in bank deposits and reserves, as well as bills in favor of non-financial agents. However, the sale of public securities in the non-banking private sector can cause upward pressure on interest rates. In fact, in order to attract funds, the Treasury can offer higher interest rates. Increasing interest rates diverts the funds of private sector to the public sector, and will cause a decline in private spending and, in particular private investment. Consequently, private borrowers risk having to use even more banks in order to cover their needs for funding. Should that be the case, there would be no difference between the budget deficit financing by the banks and the assured through non-banking sector. Impact on monetary measure depends on the attitude of the Central Bank in relation to interest rates and giving commercial banks' liquidity. In both cases, the monetary authority intervention will be achieved by increasing the monetary base and money supply in the broad sense.

Loans contracted by the public sector abroad, do not affect the monetary mass, but to the extent that does not result in an increase in cash assets held by the private non-banking sector. This assumes that the monetary authority intervenes in the exchange market by issuing national currency against product of external debt denominated in foreign currency, in the case of fixed or administrated exchange rate regime. In contrast, in the case of a floating exchange rate regime, there is no impact on the monetary base or the monetary mass in a broad sense, as the authorities do not intervene in the exchange market.

\section{Methodology and Results}

The regression model comprises the independent variables and the dependent one. To test the relation between inflation and budget deficit for Albania, to prove if there is evidence in concluding that the budget deficit causes inflation the budget deficit to gross domestic product GDP at current prices ratio and annual change in consumer price index CPI are used. The independent variable of the model is inflation rate, whereas the dependent one is budget deficit to gross domestic product ratio BD. Data used are taken from the Ministry of Finances, Bank of Albania, and Institute of Statistics. The model equation is:

$$
\Delta \mathrm{CPI}=\alpha+\beta \mathrm{BD}+\varepsilon
$$

The Regression results are:

\begin{tabular}{lc}
\multicolumn{2}{l}{ Summary Output } \\
\hline \multicolumn{2}{c}{ Regression Statistics } \\
\hline Multiple R & 0,681712836 \\
R Square & 0,464732391 \\
Adjusted R Square & 0,42355796 \\
Standard Error & 0,081055149 \\
Observations & 15 \\
\hline
\end{tabular}

ANOVA

\begin{tabular}{lccccc}
\hline & $d f$ & $S S$ & $M S$ & $F$ & Significance $F$ \\
\hline Regression & 1 & 0,074154 & 0,074154 & 11,28692 & 0,005125 \\
Residual & 13 & 0,085409 & 0,00657 & & \\
Total & 14 & 0,159564 & & & \\
\hline
\end{tabular}

\begin{tabular}{|c|c|c|c|c|c|c|c|}
\hline & Coefficients & Standard Error & $t$ Stat & $P$-value & Lower 95\% Upper 95\% & Lower $95,0 \%$ & Upper $95,0 \%$ \\
\hline Intercept & $-0,091265897$ & 0,0512614 & $-1,7804024$ & 0,0983792 & $-0,2020094 \quad 0,0194776$ & $-0,2020094$ & 0,0194776 \\
\hline BD & 2,347533034 & 0,6987536 & 3,3596007 & 0,0051252 & $0,8379677 \quad 3,8570984$ & 0,8379677 & 3,8570984 \\
\hline
\end{tabular}


Hypothesis: Budget Deficit effects inflation rate.

From the results we derive the model equation as:

$$
\Delta \mathrm{CPI}=-0,091265897+2,347533034 \mathrm{BD}+0,0512614
$$

The R Square is 0,464732391 which shows that the relation between inflation and budget deficit is not very high, so budget deficit is not a strong determinant of inflation in Albanian case. The quality of data and its amount may be negative factors to these results. The Coefficient is 2,347533034 which means for every unit increase in Budget Deficit the Inflation would increase by that amount. The significance of 0,005125 shows that the model is significant.

Table 1: CPI and Budget Deficit in Albania

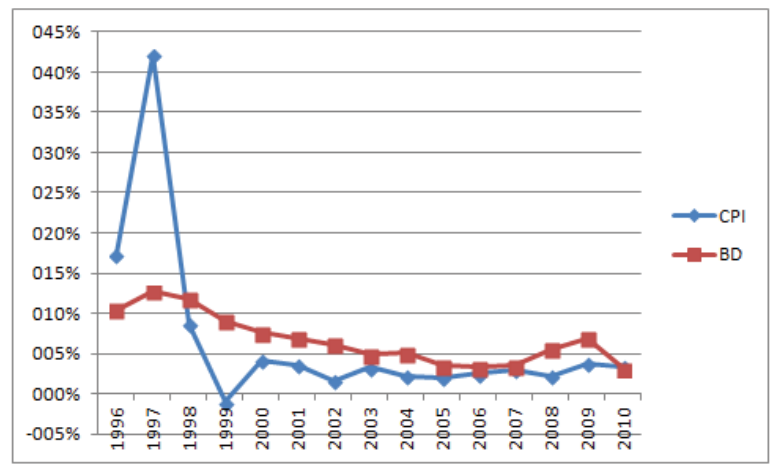

Table 2: The Linear Regression

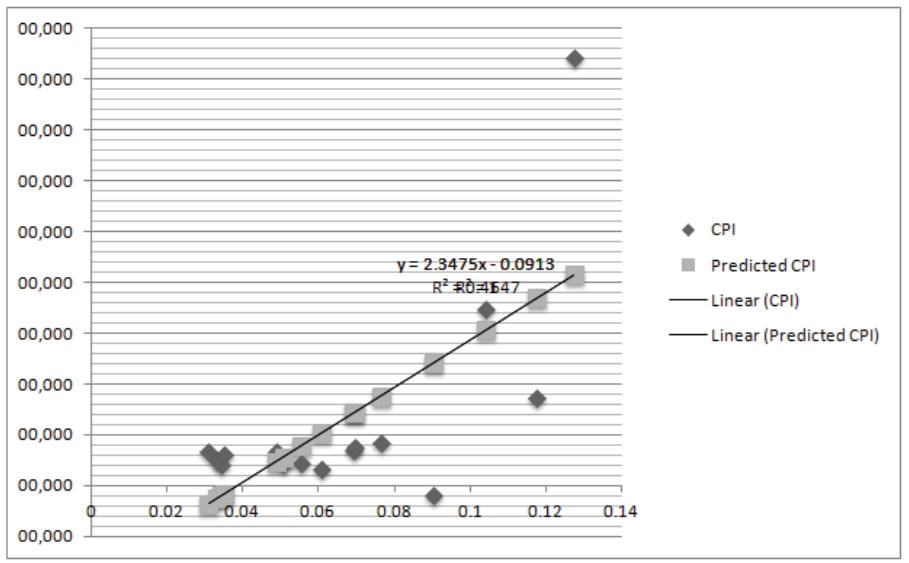

\section{Conclusion}

The researchers conducted show that the government policies toward public debt and budget deficit do not affect very much the monetary variables, as most of the Central Banks are independent from the government and do their policies independently of the government one. As one the goal of one central bank is to maintain price stability, they will not use issuing money to finance the government debts. Strong evidence between inflation and budget deficit is only found in those countries where the government does also the monetary policy of the country.

The result of the regression analysis conducted showed once more the above mentioned. In the case of Albania there was no strong evidence of this relation. The Bank of Albania being an independent institution from the central government does compose the monetary policy of Albania having as its main aim the Inflation Targeting. So the inflation in Albanian case is controlled by the central bank to maintain a range of 2 to 4 percent. 


\section{References}

Agénor P.R., Montiel P. (1994). Development Macroeconomics, Forthcoming, Princeton University Press, 126.

Anand R., Wijnbergen S. (1989). Inflation and the Financing of Government Expenditure: An Introductory Analysis with an Application to Turkey, The World Bank Economic Review, 1(3), 17-38.

Begg D., Ficher S., Dornbusch R. (1996). Macroéconomie, Ediscience, Inter-national, 2e edition, 254.

Blejer M., Cheasty A. (1988). High Inflation, Heterodox Stabilization, and Fiscal Policy, World Development, 8(16), 867-882.

Blundell-Wignall A. and Chouraqui J.C. (1981). Financement du Déficit Budgétaire et Contrôle Monétaire, L'Observateur de l'OCDE, 113, 14-18.

Bruno M. (1995). L'inflation freinetelle vraiment la croissance, Finances \& Développement, 3(32), 36.

Buiter W. (1990). Principles of Budgetary and Financial Policy,Harvester Wheatsheaf.

Coorey Sh., Mecagni M., Offerdal E. (1998). Juguler l'inflation dans les pays en transition, Finances \& Développement, 30-33.

Dornbusch R., Ficher S. (1986). Stopping Hyperinflations Past and Present, Weltwiertschaftliches Archiv, 1(122), 1-47.

Giannaros D.S., Kolluri B.R. (1985). Deficit Spending, Money, and Inflation: Some International Empirical Evidence, Journal of Macroeconomics, 3(7), 401-417.

McCallum B. (1984). Are Bond - financed Deficits Inflationary, Journal of Political Economy, 1(92), 123-135.

Modigliani F. (1987). The Economic of Public Deficits, Economic policy in Theory and in Practice, ed. Assaf Rasin and Efraim Sadka, 349. London: Macmillan.

Montiel P.J. (1989). Empirical Analysis of High Inflation Episodes in Argentina, Brazil and Israel, IMF Staff Papers, 3(36), 527-549.

Protopapadakis A. A. (1986). Is Money Growth and Inflation Related to Government Deficits, University of Pennsylvania and the Federal Reserve Bank of Philadelphia, Working Paper 86-11.

Sargent Th.J., Wallace N. (1985). Some Unpleasant Monetarist Arithmetic, Federal Reserve of Minneapolis Quarterly Review, 1(9), 1531

Sachs J D., Larrain B.F. (1993). Macroeconomics In The Global Economy, Engelewood Cliffs, New Jersey: Prentice Hall.

Sterdyniak H. (1983). Théories et pratiques du déficit public, Observations et diagnostics économiques, journal of OFCE, 3, 65-89.

Tanzi V. (1993). The Budget Deficit in Transition", IMF Staff Papers, 3(40), 697-707. 